\title{
BASIC SKILLS OF STUDENTS: READING, MATHEMATICS AND SCIENCE
}

\author{
Carmen Valentina R $\breve{A D U L E S C U}{ }^{a^{*}}$, Sorin Petrică ANGHELUT⿱艹A $\breve{~}^{b}$, \\ Sorin BURLACU ${ }^{c}$, Victor Adrian TROAC $\breve{A}^{d}$ \\ ${ }^{a, b, c, d}$ Bucharest University of Economic Studies, Romania
}

\begin{abstract}
Reading, math and science are basic skills that students acquire in school. The level of these basic skills is an important indicator of the quality of initial education and training systems. The basic competences acquired in primary and lower secondary education are assessed. The authors propose the analysis of the evolution of underachievement indicators in reading, mathematics and science in the member countries of the European Union, for the period 2006-2018. The level of education can be influenced by the existence in a community of students with poor results, associated with the existence of students with special educational needs.
\end{abstract}

KEYWORDS: basic skills, education, European Union.

\section{DOI: 10.24818/IMC/2021/02.14}

\section{INTRODUCTION}

Reading, math and science are basic skills that students acquire in school. The level of these basic skills is an important indicator of the quality of initial education and training systems. Through the International Student Assessment Program (PISA), the basic skills acquired in primary and lower secondary education are assessed.

The acquisition of basic skills requires different approaches from countries. It is noted that measures are needed to reduce poor performance in reading, mathematics and science.

The existence in a community of students with poor results, associated with the existence of students with special educational needs, decreases the level of education. Hence, a low level of education makes it possible to manifest a disadvantaged socio-economic environment for that community. In this context, in order to develop the potential and to integrate these students in the community, it is necessary to be aware of the role that vocational education and training systems play (Androniceanu \& Burlacu, 2017).

It is hoped that students' performance will not be influenced by their socio-economic status or if there is an influence it will have as little impact as possible (Stoica \& Burlacu, 2017). Also, in order to increase student performance, the quality of teacher training is very important (Burlacu \& Neagu, 2007).

The acquisition by students of those skills related to entrepreneurship, respectively the relevant skills that will allow them to occupy jobs, can be achieved only on the basis of access to quality education (Burlacu et al., 2013).

In some cases, students' educational performance may worsen when they use digital devices in the classroom (Ravizza et al., 2017). Thus, there is no correlation between students achieving improved school results based on the use of digital technology (Burlacu et al., 2018).

\footnotetext{
* Corresponding author. E-mail address: carmen-valentina.radulescu@eam.ase.ro
} 
It is also desirable that in the classroom the use of the computer be made in moderation and only for educational purposes (Vázquez-Cano et al., 2020). Students' attitude towards educational processes is also influenced by the degree of school experience that their parents have (Barg, 2019).

Applying long-term planning strategies for investment in education can help increase productivity (Rupnik and Avsec, 2020). It is found, however, that the application of different training practices is closely related to different learning environments (Asunda and Quintana, 2018).

Thus, young people can benefit from additional opportunities by applying measures that lead to an improved quality of education and training processes (EC, 2016). Learning models that rely on cooperation between peers can lead to considerably improved school outcomes (Pulgar et al., 2020).

\section{RESULTS AND DISCUSSIONS}

Creating quality, well-paid jobs cannot be based on graduates who do not have the basic skills. Also, the personal fulfillment and well-being of the members of a community can contribute to the development and prosperity of that community.

The opportunities that students can benefit from after graduation can be reduced if they have underachievement in reading, mathematics and science. The following table presents the comparative situation of underachievement in reading for 15-year-old students, in the period 2006$2018(\%)$.

Table 1. Comparative situation of underachievement in reading for 15 -year-old students, in the period 2006-2018 $(\%)$

\begin{tabular}{|c|c|c|c|c|c|}
\hline Countries & 2006 & 2009 & 2012 & 2015 & 2018 \\
\hline Belgium & 19.4 & 17.7 & 16.1 & 19.5 & 21.3 \\
\hline Bulgaria & 51.1 & 41.0 & 39.4 & 41.5 & 47.1 \\
\hline Czechia & 24.8 & 23.1 & 16.9 & 22.0 & 20.7 \\
\hline Denmark & 16.0 & 15.2 & 14.6 & 15.0 & 16.0 \\
\hline Germany & 20.0 & 18.5 & 14.5 & 16.2 & 20.7 \\
\hline Estonia & 13.6 & 13.3 & 9.1 & 10.6 & 11.1 \\
\hline Ireland & 12.1 & 17.2 & 9.6 & 10.2 & 11.8 \\
\hline Greece & 27.7 & 21.3 & 22.6 & 27.3 & 30.5 \\
\hline Spain & 25.7 & 19.6 & 18.3 & 16.2 & : \\
\hline France & 21.7 & 19.8 & 18.9 & 21.5 & 20.9 \\
\hline Croatia & 21.5 & 22.4 & 18.7 & 19.9 & 21.6 \\
\hline Italy & 26.4 & 21.0 & 19.5 & 21.0 & 23.3 \\
\hline Cyprus & $:$ & : & 32.8 & 35.6 & 43.7 \\
\hline Latvia & 21.2 & 17.6 & 17.0 & 17.7 & 22.4 \\
\hline Lithuania & 25.7 & 24.4 & 21.2 & 25.1 & 24.4 \\
\hline Luxembourg & 22.9 & 26.0 & 22.2 & 25.6 & 29.3 \\
\hline Hungary & 20.6 & 17.6 & 19.7 & 27.5 & 25.3 \\
\hline Malta & $:$ & 36.3 & $:$ & 35.6 & 35.9 \\
\hline Netherlands & 15.1 & 14.3 & 14.0 & 18.1 & 24.1 \\
\hline Austria & 21.5 & : & 19.5 & 22.5 & 23.6 \\
\hline Poland & 16.2 & 15.0 & 10.6 & 14.4 & 14.7 \\
\hline Portugal & 24.9 & 17.6 & 18.8 & 17.2 & 20.2 \\
\hline Romania & 53.5 & 40.4 & 37.3 & 38.7 & 40.8 \\
\hline Slovenia & 16.5 & 21.2 & 21.1 & 15.1 & 17.9 \\
\hline Slovakia & 27.8 & 22.2 & 28.2 & 32.1 & 31.4 \\
\hline Finland & 4.8 & 8.1 & 11.3 & 11.1 & 13.5 \\
\hline Sweden & 15.3 & 17.4 & 22.7 & 18.4 & 18.4 \\
\hline United Kingdom & 19.0 & 18.4 & 16.6 & 17.9 & 17.3 \\
\hline
\end{tabular}

Source: made by the authors based on existing data on the EUROSTAT website (2021) 
From the comparative situation presented, it is observed that underachievement in reading increased in 2018 compared to 2006 in: Luxembourg $(+6.4 \%)$, Hungary $(+4.7 \%)$, Netherlands $(+9.0 \%)$, Slovakia $(+3.6 \%)$, Finland $(+8.7 \%)$. Significant decreases in values are recorded in: Bulgaria $(-$ $4.0 \%)$, Czech Republic (-4.1\%), Estonia (-2.5\%), Italy (-3.1\%), Portugal (-4.7\%), Romania (12.7\%). However, in 2018 the countries where over a third of 15-year-old students have underachievement in reading are: Bulgaria (47.1\%), Greece (30.5\%), Cyprus (43.7\%), Luxembourg (29.3\%), Malta (35.9\%), Romania (40.8\%), Slovakia (31.4\%). Less than $15 \%$ of 15 -year-olds have underachievement in reading in: Estonia (11.1\%), Ireland (11.8\%), Poland (14.7\%), Finland $(13.5 \%)$.

The following table presents the comparative situation of underachievement in mathematics for the period 2006-2018 (\%).

Table 2. Comparative situation of underachievement in mathematics for 15-year-old students, in the period 2006-2018 (\%)

\begin{tabular}{|l|r|r|r|r|r|}
\hline Countries & \multicolumn{1}{l|}{ 2006 } & \multicolumn{1}{l}{ 2009 } & \multicolumn{1}{l}{ 2012 } & \multicolumn{1}{l}{ 2015 } & \multicolumn{1}{l|}{ 2018 } \\
\hline Belgium & 17.5 & 19.1 & 19.0 & 20.1 & 19.7 \\
\hline Bulgaria & 53.4 & 47.1 & 43.8 & 42.1 & 44.4 \\
\hline Czechia & 19.3 & 22.4 & 21.0 & 21.7 & 20.4 \\
\hline Denmark & 13.7 & 17.1 & 16.8 & 13.6 & 14.6 \\
\hline Germany & 20.0 & 18.7 & 17.7 & 17.2 & 21.1 \\
\hline Estonia & 12.1 & 12.7 & 10.5 & 11.2 & 10.2 \\
\hline Ireland & 16.5 & 20.9 & 16.9 & 15.0 & 15.7 \\
\hline Greece & 32.5 & 30.4 & 35.7 & 35.8 & 35.8 \\
\hline Spain & 24.8 & 23.8 & 23.6 & 22.2 & 24.7 \\
\hline France & 22.4 & 22.5 & 22.4 & 23.5 & 21.3 \\
\hline Croatia & 28.7 & 33.2 & 29.9 & 32.0 & 31.2 \\
\hline Italy & 33.0 & 25.0 & 24.7 & 23.3 & 23.8 \\
\hline Cyprus & & & 42.0 & 42.6 & 36.9 \\
\hline Latvia & 20.8 & 22.6 & 19.9 & 21.4 & 17.3 \\
\hline Lithuania & 23.1 & 26.4 & 26.0 & 25.4 & 25.6 \\
\hline Luxembourg & 22.9 & 23.9 & 24.3 & 25.8 & 27.2 \\
\hline Hungary & 21.2 & 22.3 & 28.1 & 28.0 & 25.6 \\
\hline Malta & & 33.7 & $:$ & 29.1 & 30.2 \\
\hline Netherlands & 11.6 & 13.4 & 14.8 & 16.7 & 15.8 \\
\hline Austria & 20.1 & & 18.7 & 21.8 & 21.1 \\
\hline Poland & 20.0 & 20.5 & 14.4 & 17.2 & 14.7 \\
\hline Portugal & 30.9 & 23.8 & 24.9 & 23.8 & 23.3 \\
\hline Romania & 52.9 & 47.0 & 40.8 & 39.9 & 46.6 \\
\hline Slovenia & 17.8 & 20.4 & 20.1 & 16.1 & 16.4 \\
\hline Slovakia & 21.0 & 21.0 & 27.5 & 27.7 & 25.1 \\
\hline Finland & 6.0 & 7.9 & 12.3 & 13.6 & 15.0 \\
\hline Sweden & 19.4 & 21.1 & 27.1 & 20.8 & 18.8 \\
\hline United Kingdom & 20.2 & 21.8 & 21.9 & 19.2 \\
\hline
\end{tabular}

Source: made by the authors based on existing data on the EUROSTAT website (2021)

It is observed that in 2018, compared to 2006, the values decreased in: Bulgaria (-9.0\%), Italy $(-9.2 \%)$, Latvia (-3.5\%), Poland (-5.3\%), Portugal (-7.6\%), Romania (-6.3\%). Also, the most significant increases in values were registered in: Greece $(+3.3 \%)$, Luxembourg $(+4.3 \%)$, Hungary $(+4.4 \%)$, Netherlands $(+4.2 \%)$, Slovakia $(+4.1 \%)$, Finland $(+9.0 \%)$. In 2018, the countries where 
over a third of 15-year-old students have underachievement in mathematics are: Bulgaria (44.4\%), Greece $(35.8 \%)$, Croatia (31.2\%), Cyprus (36.9\%), Malta (30.2\%), Romania (46.6\%). Less than $15 \%$ of 15 -year-old students have underachievement in mathematics in: Denmark (14.6\%), Estonia $(10.2 \%)$, Poland (14.7\%), Finland (15.0\%).

Table 3. Comparative situation of underachievement in science for 15-year-old students, in the period 2006-2018 $(\%)$

\begin{tabular}{|l|r|r|r|r|r|}
\hline Countries & \multicolumn{1}{l|}{ 2006 } & \multicolumn{1}{l}{ 2009 } & \multicolumn{1}{l|}{ 2012 } & \multicolumn{1}{l|}{ 2015 } & \multicolumn{1}{l|}{ 1018 } \\
\hline Belgium & 17.0 & 18.0 & 17.7 & 19.8 & 20.0 \\
\hline Bulgaria & 42.6 & 38.8 & 36.9 & 37.9 & 46.5 \\
\hline Czechia & 15.5 & 17.3 & 13.8 & 20.7 & 18.8 \\
\hline Denmark & 18.4 & 16.6 & 16.7 & 15.9 & 18.7 \\
\hline Germany & 15.4 & 14.8 & 12.2 & 17.0 & 19.6 \\
\hline Estonia & 7.7 & 8.3 & 5.0 & 8.8 & 8.8 \\
\hline Ireland & 15.5 & 15.2 & 11.1 & 15.3 & 17.0 \\
\hline Greece & 24.0 & 25.3 & 25.5 & 32.7 & 31.7 \\
\hline Spain & 19.6 & 18.2 & 15.7 & 18.3 & 21.3 \\
\hline France & 21.2 & 19.3 & 18.7 & 22.1 & 20.5 \\
\hline Croatia & 17.0 & 18.5 & 17.3 & 24.6 & 25.4 \\
\hline Italy & 25.3 & 20.6 & 18.7 & 23.2 & 25.9 \\
\hline Cyprus & & & 38.0 & 42.1 & 39.0 \\
\hline Latvia & 17.4 & 14.7 & 12.4 & 17.2 & 18.5 \\
\hline Lithuania & 20.3 & 17.0 & 16.1 & 24.7 & 22.2 \\
\hline Luxembourg & 22.1 & 23.7 & 22.2 & 25.9 & 26.8 \\
\hline Hungary & 15.0 & 14.1 & 18.0 & 26.0 & 24.1 \\
\hline Malta & $:$ & 32.5 & $:$ & 32.5 & 33.5 \\
\hline Netherlands & 13.0 & 13.2 & 13.1 & 18.5 & 20.0 \\
\hline Austria & 16.3 & & 15.8 & 20.8 & 21.9 \\
\hline Poland & 17.0 & 13.1 & 9.0 & 16.3 & 13.8 \\
\hline Portugal & 24.5 & 16.5 & 19.0 & 17.4 & 19.6 \\
\hline Romania & 46.9 & 41.4 & 37.3 & 38.5 & 43.9 \\
\hline Slovenia & 13.9 & 14.8 & 12.9 & 15.0 & 14.6 \\
\hline Slovakia & 20.2 & 19.3 & 26.9 & 30.7 & 29.3 \\
\hline Finland & 4.1 & 6.0 & 7.7 & 11.5 & 12.9 \\
\hline Sweden & 16.4 & 19.1 & 22.2 & 21.6 & 19.0 \\
\hline United Kingdom & 16.7 & 15.0 & 15.0 & 17.4 & 17.4 \\
\hline
\end{tabular}

Source: made by the authors based on existing data on the EUROSTAT website (2021)

In 2018, the countries where over a third of 15-year-old students have underachievement in science are: Bulgaria $(46.5 \%)$, Greece $(31.7 \%)$, Cyprus (39.0\%), Malta (33.5\%), Romania (43.9\%), Slovakia $(29.3 \%)$. Less than $15 \%$ of 15 -year-old students have underachievement in science in: Estonia (8.8\%), Poland (13.8\%), Slovenia (14.6\%), Finland (12.9\%). It is also noted that in 2018, compared to 2006, the values decreased in: France (-0.7\%), Poland (-3.2\%), Portugal (-4.9\%), Romania (-3.0\%). Also, the most significant increases in values were registered in: Greece $(+7.7 \%)$, Croatia (+8.4\%), Hungary $(+9.1 \%)$, Netherlands $(+7.0 \%)$, Austria $(+5.6 \%)$, Slovakia $(+9.1 \%)$, Finland $(+8.8 \%)$.

From the analysis, it can be concluded that, in 2018, in some countries educational underachievement has high values for all indicators (reading, mathematics, science). In the following countries over a third of 15-year-old students have underachievement for reading, 
mathematics and science: Bulgaria, Cyprus, Greece, Malta and Romania. Figure 1 shows the comparative situation of the values for the 3 indicators in these countries.

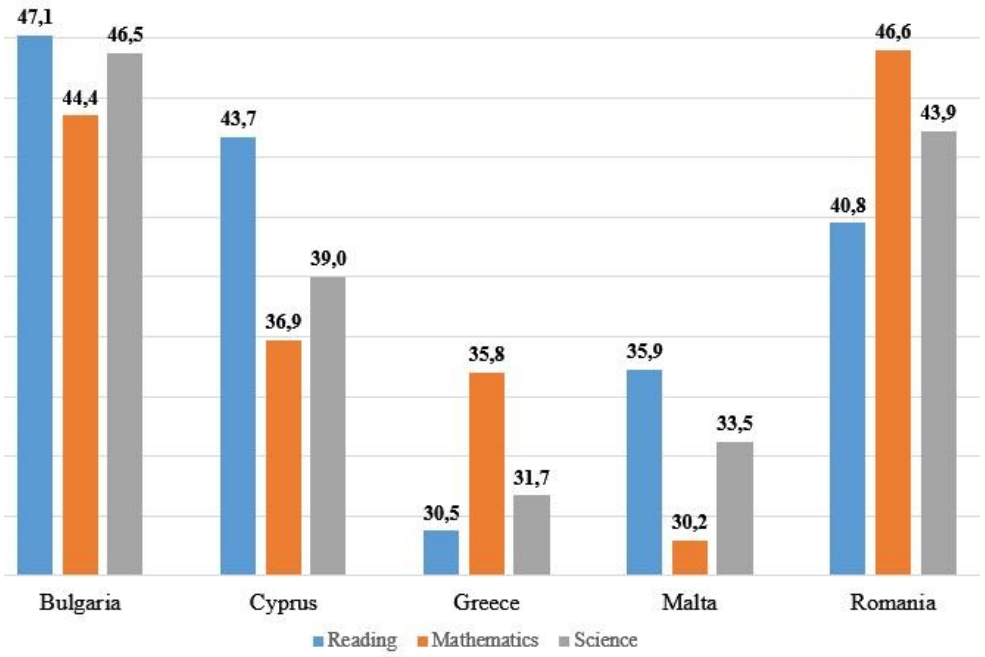

Figure 1. The comparative situation of values for reading, mathematics, science in Bulgaria, Cyprus, Greece, Malta and Romania

Source: made by the authors based on existing data on the EUROSTAT website (2021)

Considering the values from the previous figure, we notice that the countries where underachievement for reading, mathematics and science have the highest values are: Bulgaria and Romania.

At the same time, less than $15 \%$ of 15 -year-old students have underachievement for reading, mathematics and science in: Estonia, Finland and Poland. The following figure shows the comparative analysis for these countries.

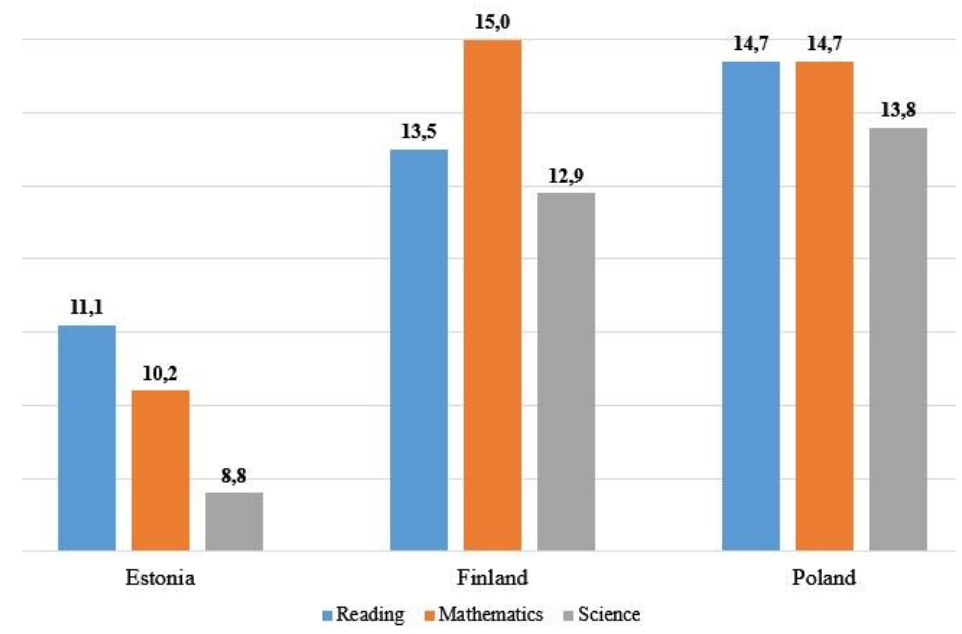

Figure 2. The comparative situation of values for those reading, mathematics, science in Estonia, Finland and Poland

Source: made by the authors based on existing data on the EUROSTAT website (2021)

From the data presented in this figure, it is observed that in Estonia the lowest values of the 3 indicators (underachievement for reading, mathematics and science) are registered. 


\section{CONCLUSIONS}

Their participation in education and training programs also contributes to increasing the level of skills of graduates. Bringing educational processes closer to the labor market is a more common requirement. In this way, there are changes in working methods in the teaching of disciplines (Chari and Potvin, 2019).

From the analysis, it can be concluded that, in 2018, in some countries educational underachievement has high values for all indicators (reading, mathematics, science). In Bulgaria, Cyprus, Greece, Malta and Romania over a third of 15-year-old students have: underachievement for reading, mathematics and science. Also, in terms of the three indicators, the results are better: Estonia, Finland and Poland.

The need for education of students is influenced by economic and social characteristics, but also by demographic characteristics. The education they received, as well as its quality, contributes to the performance of graduates. In situations that require change, the acquisition of relevant civic, social and entrepreneurial skills can lead to increased capacity to adapt to these changes (OECD, 2019). Underachievement in reading, maths and science can lead to marginalization and social exclusion, respectively. It is considered that participation in education and training programs contributes to the elimination of these negative manifestations (ECA, 2017).

\section{REFERENCES}

Androniceanu, A., \& Burlacu, S. (2017). Integration of Educational Technologies in Universities and Students'Perception Thereof. In The International Scientific Conference eLearning and Software for Education(Vol. 2, p. 26). "Carol I" National Defence University.

Androniceanu, A., \& Burlacu, S. (2017). Intelligent System for Assessment and Grading Based on Docimologic Tests. eLearning \& Software for Education, 2.

Asunda, P. A., \& Quintana, J. (2018). Positioning the T and E in STEM: A STL Analytical Content Review of Engineering and Technology Education Research. Journal of Technology Education, $30(1)$.

Barg, K. (2019). Why are middle-class parents more involved in school than working-class parents? Research in Social Stratification and Mobility, 59, 14-24.

Burlacu, S., \& Neagu, C. (2007) E-Learning or Electronic Systems of Training. Management And Marketing, 823.

Burlacu, S., Rădulescu, C. V., \& Bălu, O. F. (2018). Forms of Electronic Training. Principles of Educational Games. In Proceedings Of The International Conference on Economics and Social Sciences (Vol. 1, pp. 36-41). Bucharest University of Economic Studies, Romania.

Chari, D., \& Potvin, G. (2019). Understanding the importance of graduate admissions criteria according to prospective graduate students. Physical Review Physics Education Research, 15, 023101.

European Commission (2016). Communication from the Commission to the European Parliament, the Council, the European Economic and Social Committee and the Committee of the Regions 'Next steps for a sustainable European future European action for sustainability'

European Court of Auditors (2017). Special report No 5/2017: Youth unemployment - have EU policies made a difference? Retrieved June 30, 2021, from: https://www.eca.europa.eu/en/Pages/DocItem.aspx?did=41096.

EUROSTAT. (2021). http://ec.europa.eu/eurostat

Organization for Economic Cooperation and Development (2019). Trends Shaping Education 2019, OECD Publishing, Paris. Retrieved June 27, 2021, from: https://read.oecdilibrary.org/education/trends-shaping-education-2019_trends_edu-2019-en. 
Pulgar, J., Candia, C., \& Leonardi, P. M. (2020). Social networks and academic performance in physics: Undergraduate cooperation enhances ill-structured problem elaboration and inhibits well-structured problem solving. Physical Review Physics Education Research, 16, 010137.

Ravizza, S. M., Uitvlugt, M. G., Fenn, K. M. (2017). Logged In and Zoned Out: How Laptop Internet Use Relates to Classroom Learning. Psychological Science, 28(2), 171-180.

Rupnik, D., \& Avsec, S. (2020). Effects of a transdisciplinary educational approach on students' technological literacy. Journal of Baltic Science Education, 19(1), 121-141.

Stoica, M. M., \& Burlacu, S. (2017) Concepts and Trends on E-Learning in Romania. The International Journal of Engineering And Science (IJES), 6(3), 100-105, ISSN (e): 2319 $1813 \operatorname{ISSN}(\mathrm{p}): 2319-1805$

Vázquez-Cano, E., Gómez-Galán, J., Infante-Moro, A., \& López-Meneses, E. (2020). Incidence of a Non-Sustainability Use of Technology on Students' Reading Performance in Pisa. Sustainability, 12, 749 . 